\title{
NHT Assisted LKS Based Visual Thinking: Emerging Critical Thinking Ability for Prospective Teacher
}

\author{
Wardatul Jannah and Christina Ismaniati
}

Universitas Negeri Yogyakarta, Yogyakarta

\section{Abstract}

This study is classroom action research (PTK) conducted in 2 cycles. The study aims to improve students' critical thinking ability of class II F PGSD UNY in the science education course, through the application of NHT assisted LKS based on visual thinking. Instruments used in this study are the instruments of critical thinking ability, interviews, and $\mathrm{NHT}$ assisted LKS based on visual thinking implementation instruments. The results showed that the implementation of $\mathrm{NHT}$ assisted LKS based visual thinking can improve students' critical thinking ability. This is evidenced by the increase in the percentage of critical thinking ability in every cycle. In cycle I the percentage of critical

Corresponding Author:

Wardatul Jannah

wardatuljannah.2017@student uny.ac.id

Received: 23 January 2019 Accepted: 26 February 2019 Published: 17 March 2019

Publishing services provided by Knowledge E

(c) Wardatul Jannah and Christina Ismaniati. This article is distributed under the terms of the Creative Commons

Attribution License, which permits unrestricted use and redistribution provided that the original author and source are credited.

Selection and Peer-review under the responsibility of the International Seminar on Language, Education, and Culture Conference Committee. thinking ability reached $69.5 \%$ with moderate category being increased in the second cycle reached $80.4 \%$ with high category. The students' critical thinking ability improved significantly as well as the normalized gain test results from pretest (post-test $=0.11$ ) and post-test (cycle $2=0.47$ ) of 0.38 in the moderate category. In addition, the results of the study also showed an increase in the percentage of implementation NHT assisted LKS based on visual thinking in the first cycle which reached $80.2 \%$ with good category increased in the second cycle reached $97.2 \%$ with very good category.

This study is a classroom action research (PTK) conducted in 2 cycles. The study aims to improve students' critical thinking ability of class II F PGSD UNY in the science education course, through the application of NHT assisted LKS based on visual thinking. Instruments used in this study are the instruments of critical thinking ability, interviews, and $\mathrm{NHT}$ assisted LKS based on visual thinking implementation instruments. The results showed that the implementation of NHT assisted LKS based visual thinking can improve students' critical thinking ability. This is shown by the increase in the percentage of critical thinking ability in every cycle. In cycle I the percentage of critical thinking ability reached $69.5 \%$ with moderate category being increased in the second cycle reached $80.4 \%$ with high category. The students' critical thinking ability improved significantly as well as the normalized gain test results from pretest (post-test $=0.11$ ) and post-test (cycle $2=0.47$ ) of 0.38 in the moderate category. In addition, the results of the study also showed an increase in the percentage of implementation NHT assisted LKS based on visual thinking in the first cycle which reached $80.2 \%$ with good category increased in the second cycle reached $97.2 \%$ with very good category.

Keywords: NHT, LKS, visual thinking, critical thinking 


\section{Introduction}

Education is one of the places to prepare human resources in facing the era of globalization. This era requires everyone to have the ability to compete in terms of aspects of life. Kaufman (2013), integrates the various capabilities that are confirmed in the TFCS which includes the ability to think critically. Knapp \& Glenn (1996: 128) explains that critical thinking is a person's ability to analyze ideas or opinions, compare opposing views, decision-making and ability in other analytical processes. Indicators that can be used for measuring critical thinking is elementary clarification, basic support, inference, advanced clarification, and strategies and tactics (Nitko \& Bookhart, 2011). By having these capabilities, it is expected that people will have the opportunity to be able to face various challenges and be responsive to the needs and problems that need to be faced in the current times. Therefore, this ability is very important to be trained and instilled in the students, as well as on Department of Primary School Teacher Education (Program studi Pendidikan Guru Sekolah Dasar/ PGSD) students as future educators. This ability is able to assist students in analyzing and evaluating the various theories that need in learning. So they can carefully design, present the material and carry out the learning process in accordance with the theory and needs of the era that will be applied in elementary school.

In fact, based on the results of observations and interviews on the implementation of learning in Science education subject showed the lack of critical thinking abilities of students at class II F. It was seen from the answers and the behavior of students when getting questions. Students tended to answer questions by using statements that are in the book without developing the answer with students' knowledge relating to the question. Students also found difficulty in analyzing a comparison and getting confuse in making conclusions from the material or examples of problems that were given.

Mr. Ikhlasul, M. Pd as a lecturer of Science subject also reinforced the lack of students' ability in critical thinking. He explained that when students were assigned to make a resume from the manual, students tended to write only summaries by copying text that had been translated in a language translation application without analyzing or evaluating it. To proved the existence of that case, then the students were given the pre-test as a step to determine the students' critical thinking abilities. The data showed that students' critical thinking ability score was $62.4 \%$. This value is categorized into low level. Here is the data shown in detail:

After seeing the phenomenon and problems found in the data above, researcher offer solutions to apply Number Head Together (NHT) assisted student worksheet (LKS) 
TABLE 1: The Data of Critical Thinking Ability of Students.

\begin{tabular}{|c|c|}
\hline No & Critical Thinking Indicators \\
\hline a. & Elementary clarification \\
\hline b. & Basic support \\
\hline c. & Strategies and tactics \\
\hline d. & Advanced clarification \\
\hline e. & Inference \\
\hline \multicolumn{2}{|c|}{ Critical Thinking Ability } \\
\hline
\end{tabular}

\begin{tabular}{|c|}
\hline Scores (\%) \\
\hline 64,7 \\
\hline 61,5 \\
\hline 62,2 \\
\hline 64,7 \\
\hline 58,9 \\
\hline 62,4 \\
\hline
\end{tabular}

\begin{tabular}{|c|}
\hline Categories \\
\hline Moderate \\
\hline Low \\
\hline Low \\
\hline Moderate \\
\hline Low \\
Low
\end{tabular}

based on visual thinking. Kusumaningtyas (2013) describes that NHT had the procedures established explicitly to give students more time to think, respond, and help each other to answer dan solve a problem. Thus, NHT allows all students to be involved in analyzing, evaluating and concluding information according to the questions that are given.Then students are ensured to know the problem or the result in discussion activities. This process is expected to develop students' critical thinking ability. The learning steps of $\mathrm{NHT}$ are numbering, questioning, thinking together, and answering (Arends, 2009).

Questioning through NHT is done using the student worksheet. It helps students easier answer the question. Therefore, LKS is designed based on visual thinking. Visual thinking is central to all thought mapping. Visual thinking can refer to mindscape, mind mapping, and depiction of symbols / images and other words used in describing thinking (Santiago, 2011). Margulies \& Valenza (2008: 8) describes visual mapping used in improving thinking ability in many ways and as a primary source in finding and creating symbols. The existence of images, symbols, words, colors and mapping will be able to stimulate students in thinking to remember and generate ideas needed for critical thinking. It can happen because visual thinking basically is a brain-friendly thinking tool. This visual thinking helps the brain to make a big imagination through associations that encourage synergistic thinking in generating and organizing ideas to generate critical thinking (Hyerle \& Alper, 2011).

Based on the description above, researchers conduct classroom action research. Researchers want to improve students' critical thinking ability at class II F PGSD UNY. Researchers take a focus on the learning that is conducted using NHT, which is in the step of questioning is assisted by LKS based on visual thinking. Thus, students are expected to actively participate in answering and developing visual thinking through various analysis and evaluation. Specifically, the research aims in this study is formulated in the following statement:

1. How does NHT assisted LKS based on visual thinking improve students' critical thinking ability at class II F PGSD UNY? 


\section{Method}

This research is a classroom action research (PTK). Creswell $(2012,577)$ explains "action research designs are systematic procedures done by teachers (or other individuals in an educational setting) to gather information about, and subsequently improves, the ways they mean educational setting operates, their teaching, and their student learning". This research was conducted in March until June 2017 on science education. The subject of this class action research was 2F students of PGSD Program at Yogyakarta State University (UNY) in academic year 2017/2018 with the number of students were 39 students.

The research was conducted in 2 cycles, each cycles consists of 3 meetings. The last day of each cycle was used to evaluate students' critical thinking ability. The research design used was Kemmis and McTaggart research model through several stages of planning, implementation and observation, and reflection. The research procedure was done by giving an action by analyzing the situation and condition in the lecture then arranged action plan to be done. Furthermore, the researcher was involved as a whole in preparing the action plan, implementing and observing the action, reflect the action, until there is an appropriate improvement of research success indicators. Action activities were carried out repeatedly (cycle), to be sure of the success of the action. A technique and an instrument of data collection were using tests and non tests. The test technique was used to measure students' critical thinking ability. Assessment of critical thinking ability was done by giving the questions that were arranged based on the indicator of critical thinking ability. Non-test techniques used observation (instrument to see the implementation of the supplie), interviews and documentation.

The data result from observation of $\mathrm{NHT}$ assisted LKS based on visual thinking implementation and data of students' critical thinking ability test were analyzed by descriptive percentage technique. The formula used was (Setyowati, 2011):

$$
\text { Percentage }=\frac{\text { score }}{\text { maximum score }} \times 100 \% 100 \%
$$

The formula was used to analyze observational data using NHT based on visual thinking and data of critical thinking skill ability result. Then the percentage results were interpreted with 5 categories of interpretation according to Setyowati (2011). Furthermore, to see the increase of dependent variable (critical thinking ability), then used $\mathrm{N}$-gain score $<\mathrm{g}\rangle$ to see the improvement of students' critical thinking ability before and after the implementation of the action and then converted into table criteria. The formula N-Gain (Hake, 1999: 65) is:

$$
<\mathrm{g}>=\frac{\text { PostTest Score }- \text { PreTest Score }}{\text { Maximum Score }- \text { PreTest Score }}
$$


The processed data was then converted. Categories of percentage score were very good / high (8, 25\% <X $\leq 100 \%)$; good / high (71.5\% <X $\leq 81.25 \%)$; moderate (62.5\% $<X$ $\leq 71.5 \%)$; low (43, 75\% $<X \leq 62.5 \%)$; very bad (0\%, $\backslash<X \leq 43,75 \%)$ (Setyowati, 2011). Furthermore, the increase of dependent variable (critical thinking ability), could be known using $\mathrm{N}$-gain score $\langle\mathrm{g}\rangle$, with high criterion $(0,71-1,00)$, moderate $(0,3-0,70)$, low $(0,0$ 0.30) (Hake, 1998, p.65), to see improvements in students' critical thinking ability before (pre-cycle) and after action (cycle I and cycle II).

An action can be successful, if it has reached the criteria that have been set. Indicators of success in this research are: (1) Implementation of learning with NHT based on visual thinking has fulfilled the overall learning steps with a minimum percentage of $80 \%$ with the "good" category; (2) The critical thinking ability of students from all students reaches a minimum percentage of $80 \%$ with high category. As well as an increase in gain through a normalized gain test that is in the moderate minimum category.

\section{Findings and Discussion}

\subsection{Initial condition}

Initial conditions were known through observation, interview and Pre-test conducted by researchers. Based on the results of observations and interviews conducted on lecturers of "science lessons" subjects and students of class II F PGSD UNY on Thursday, March 1, 2018 showed some things related to students' critical thinking ability and how the implementation of learning. These observations and interviews indicated the low level of students' critical thinking ability and the conventional implementation of learning. If it was done continuously it would make it difficult to improve students' critical thinking ability because of the space and opportunities given to the students to think very less.

The results of the first test conducted on 8 March also reinforced previous indications about the low ability of students' critical thinking. The test result showed the percentage of students' critical thinking ability reached $62.4 \%$ with low category. From the problems that have been described, it was necessary to design measures to improve the quality of learning in science lessons, especially related to improving students' critical thinking ability as a candidate for educators in the 21 st century. 


\subsection{Cycle I}

The first cycle of action started with the planning of the lecture, which involved preparing Rencana Pembelajaran Semester (RPS), creating Satuan Acara Perkuliahan (SAP) of meetings 1 and 2 by applying the NHT assisted LKS based visual thinking and developing the research instrument. Second, carried out lecture activities that had been made in accordance with SAP, then observation of implementation NHT assisted LKS based on visual thinking and students' critical thinking ability. The results of the action showed that the implementation of NHT assisted LKS based on visual thinking had fulfilled the success indicator. Implementation of learning had passed the percentage of $80 \%$ with good category although some indicators didn't reach the maximum percentage, such as (1) presentation information (66,7\%), (2) numbering $66,7 \%$, (3) heads together $66,7 \%$, and (4) answering $80.2 \%$. In addition to the implementation of learning, also known as the test results of students' critical thinking ablity. Although the test results showed there was an increase in ability, but the results could not be said to be successful in this study. Percentage on each critical thinking indicator (elementary clarification $71,5 \%$, basic support $68,7 \%$, inference $66,7 \%$, advanced clarification $72,9 \%$, and strategies and tactics $67,9 \%$ ) showed varying percentage results and all were in the moderate category. While the overall percentage of critical thinking ability of all students reached the percentage of $69.9 \%$ with the moderate category and the improvement of students' critical thinking ability before and after the action (cycle l) was performed by $\mathrm{N}$-gain $<\mathrm{g}>$ of 0.19 which means that the increase going low. These results had not been able to meet the success indicators of the study. Therefore, considering there were still shortcomings and opportunities to improve, this research was continued in cycle II.

According to the results of reflection on the first cycle there were several things that were considered and improved for the next cycle, those were: (1) Lecturers had not been able to divide the time as well as possible, so that when the answer session (calling number to answer) and the provision of opportunities only a few questions that could answered and responded by other groups; (2) The task of the group had not run as desired, the student was still dependent on the lecturer, they asked too many to lecturers so mostly the problem solving ideas were still coming from the lecturer; (3) The low tone of voice owned by the lecturer, it couldn't reach the whole room so that students often asked the lecturer to do re-explanation; (4) Students were less orderly during the transfer to gather with the group. 


\subsection{Cycle II}

Cycle II was carried out in the same procedure as in cycle I, but by observing and correcting the deficiencies that occur in cycle I. Data analysis of the implementation of learning with NHT assisted LKS based on visual thinking in cycle II showed the percentage of implementation reached $97,2 \%$ with very good category which means the indicator of success had been achieved. This was because almost all percentage indicators reached maximum value except on the delivery of goals, with the percentage of 83.3\%. Analysis of critical thinking ability also showed the indicator of the success of research that had been achieved. Percentage of each indicator (elementary clarification $80,2 \%$, basic support 78,7 \%, inference 79, $3 \%$, advanced clarification $84,5 \%$, and strategies and tactics 79, $3 \%$ ) showed varying percentage results but all were in high category. The whole calculation then showed the percentage of critical thinking ability of all students reaching $80.4 \%$ with high category and $\mathrm{N}$-gain $\langle\mathrm{g}\rangle$ of 0.47 which means that the improvement was in the moderate category. Tus, all indicators of successful research had been achieved, so this classroom action research was stopped until cycle II.

\section{Discussion}

The research that discusses the application of NHT assisted LKS based on visual thinking shows findings that the NHT assisted LKS based on visual thinking can develop PGSD students' critical thinking ability as a prospective teacher. The learning was carried out with $\mathrm{NHT}$ through the stages of numbering, questioning, heads together, and answering. Qiving questions in the learning process will be provided with the help of LKS based visual thinking. The learning process has a positive impact on students' critical thinking ability. Although all students still have not gotten the most out, most of their critical thinking ability have improved. Pre-action (pre-cycle) and post-action (cycle I and cycle II) results indicated an increase. The recapitulation of research results are listed in table

2. below;

TABLE 2: Recapitulation of Research Results.

Cycles
Pre-test
Cycle I
Cycle II

\begin{tabular}{|c} 
NHT assisted LKS ba \\
Percentage \\
\hline $80,2 \%$ \\
$97,2 \%$
\end{tabular}

Categorie
on visual thinking
Good
Very good

\section{Students' critical thinking} Percentage $62,4 \%$ (low) $69,5 \%$ (moderate) $80,4 \%$ (high)

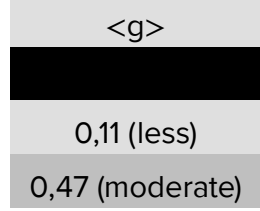


While the figure below is a figure of the improvement of the implementation of the action and the ability of students' creative thinking.

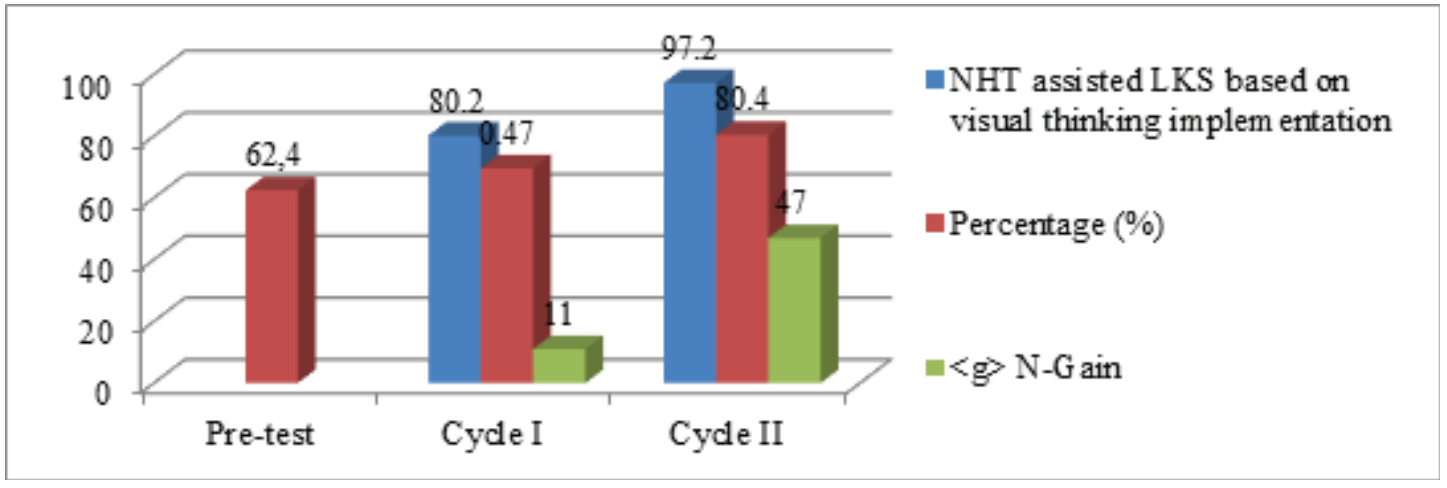

Figure 1: Increased Critical Thinking Ability and Learning Implementation.

The success of this study can not be separated from improvements made in the implementation of NHT assisted LKS based on visual thinking. The deficiencies that occur in the first cycle were fixed. Learning process was carried out optimally because: (1) Lecturers had been able to divide the time well so that the question and answer session and the giving of opportunity, and drawing conclusion by lecturer and student could run well; (2) Learning had taken place in accordance with NHT steps even though the student still needed guidance on certain steps; (3) Lecture's voice in explanation had been well noticed; (4) Students were disciplined in assembling with their groups because the lecturer informs the group members before the learning began and asked the students to sit close together so that it didn't take long.

The success of the achievement of the indicator shows that the application of NHT assisted LKS base on visual thinking that has been done optimally according to the rules and syntax able to improve PGSD students' critical thinking ability. This is because the $\mathrm{NHT}$ is able to facilitate students to actively engage in thinking and expressed opinion because in the implementation of this NHT technically encourages every student to know the answers or the results of heads together group. This is also reinforced by Novitasari (2015) which explains that NHT requires students to actively understand the subject matter personally to seek information, analyze problems, formulate problems, solve problems, provide relevant reasons, and summarize issues. That process then encourages the development of students' critical thinking ability. In addition, the lessons learned using NHT make students not bored in learning. Students look enthusiastic in every stage. They work together and mutually correct answers. Wijayanti et al (2017) also explains the point that NHT attracts students so as to attract the participation of students to engage in learning. 
The development of students' critical thinking ability is also supported by the use of LKS based on visual thinking at the answering stage. Through student LKS based on visual thinking, students can see how ideas are connected so they can be aware of how information can be grouped and organized. This causes the students ideas can be aroused so as to help students in developing critical thinking. This explanation is supported by IARE (Margulies \& Valenza, 2008: 14) which explains that visual thinking as a record system is able to assist students in improving critical thinking ability and high order thinking ability. The usefulness can occur because visual thinking helps the student to display most of the information and display a particular relationship or pattern of a concept in a more understandable way.

In addition, visual thinking is recognized to facilitate students to focus on the essentials of the tasks provided. So it can help students in analyzing and evaluating a problem. Students can filter information very easily because visual thinking as a bookmark organizing information. This is certainly not surprising, because the explanation Savage \& Armstrong (1996: 234) also strengthens, they explain that visual thinking is a technique that helps students monitoring their thinking process.

Visual thinking is used in learning is also very interesting students. For example, mind mapping, students can play with various pictures and colors that is technically very interested for students. The non-boring learning model combined with fun workmanship techniques makes students feel interested in learning. Therefore, every ability to be developed is easily encouraged to be developed. Rijavec's (2015: 229) opinion reinforces that being happy is the key to achieving any positive goal.

\section{Conclusions and Suggestions}

The implementation of 4 stages of NHT-assisted LKS based on visual thinking in the subject of Science Education is very well executed and it can improve students' critical thinking ability. Each cycle of percentage of students' thinking ability is always increasing. students' critical thinking ability increased significantly between pre cycle and cycle II, proven based on normalized gain test results of 0.47 in the moderate category.

Based on the results of these studies then the suggestions that can be given are (1) the application of NHT assisted LKS based on visual thinking in science lesson or in other lessons should be reused to create the candidate of critical thinking educator in this $21 \mathrm{st}$ century, (2) for other readers / researchers, if conducting research on implementation NHT assisted LKS based on visual thinking to make the deficiencies in this research as a consideration in planning the research, so that the results of research become better. 


\section{References}

[1] Arends, L. I. (2009). Learning to teach 9th edition. US: Mac Graw-Hill Company.

[2] Creswell, J. W. (2014). Research Desain: Qualitative, Quantitative and Mix Method Approaches. Thousands Oaks: SAGE Publication, Inc.

[3] Hake, R. R. (1998). Interactive Engagement vs Traditional Method. The american Journal of Physic Research, 66 (1), 64-74. doi: 10.1119/1.18809

[4] Hyerle, D. N., \& Alper, L. (2011). Thinking Maps. Thousands Oaks: SAGE Publication, Inc.

[5] Kaufman, K. J. (2013). 21 Ways to 21st Century Skills: Why Students Need Them and Ideas for Practical Implementation. KAPPA DELTA PI RECORD. 49, 78-83. doi: 10.1080/00228958.2013.786594

[6] Knapp, I., R., \& Glenn, A., D. (1996). Restructuring Schools with Technology. USA: A Simon and Schuster Company.

[7] Kusumaningtyas, A. (2013). The effects of problem based learning strategies combined numbered heads together towards on metacognitive ability, critical thinking and cognitive biology. Educational Research Journal, 23.

[8] Margulies, N., \& Valenza, C. (2005). Visual Thinking: Tools for Mpping Your Idea. United States of America: Grown House Publishing Company.

[9] Nitko, AJ. \& Brookhart, S,M. (2011). Educational Assesment of Students Boston. MA: Pearson.

[10] Novitasari, A. (2015). Upaya Meningkatkan Kemampuan Berpikir Kritis Siswa melalui Model Pembelajaran Kooperatif Tipe Numbered Heads Together (NHT) pada Siswa Kelas VII D SMP Negeri 11 Yogyakarta. Jurnal IImiah Mahasiswa Pendidikan Geografi FKIP Unsyiah, 1 (1), 193-202. Retrived from http://repository.upy.ac.id/304/

[11] Rijavec, M. (2015) Should happiness be taught in school?. Croatian Journal of Education, 17, 229-240. doi:10.15516/cje.v17i0.1487.

[12] Santiago, H. C. (2012). Visual Mapping to Enhance Learning and Critical Thinking Skills. Optometric Education, 36 (3), 125-139. Retrived from https://journal.opted.org/ articles/Volume_36_Number_3_VisualMapping.pdf

[13] Savage, T. V, \& Armstrong, D. G. (1996). Effective Teaching in Elementary Social Studies. New Jersey: Prentice-Hall, Inc

[14] Setyowati, A. (2011). Implementasi Pendekatan Konflik Kognitif dalam Pembelajaran Fisika untuk Menumbuhkan Kemampuan Berpikir Kritis Siswa Kelas VIII. Jurnal Pendidikan Fisika Indonesia, 7 (2). doi: 10.15294/jpfi.v7i2.1078 
[15] Wijayanti, N. W., Roemintoyo, R., \& Murwaningsih, T. (2017). The Impact of Numbered Heads Together Model on the Learning Outcomes of Science Viewed from Students' Self Regulated Learning. Journal of Education and Learning, 11 (3), 257-261. doi: 10.11591/edulearn.v11i3.5838 